\title{
Sustainability of the Moroccan Oasean System (Case study: Middle Draa Valley)
}

Ahmed Karmaoui ${ }^{*}$ Issam Ifaadassan, Mohammed Messouli and Mohammed Yacoubi Khebiza

Department of Environmental Sciences, Cadi Ayyad University, Marrakech, Morocco

*Corresponding author: Karmaoui A, Department of Environmental Sciences, Cadi Ayyad University, Marrakech, Morocco, Tel: +212-524-43-46-49; Fax: +212-524-43-67-69; E-mail: karmaoui.ahmed@gmail.com

Received date: January 08, 2015; Accepted date: January 20, 2015; Published date: January 28, 2015

Copyright: @ 2015 Karmaoui A. This is an open-access article distributed under the terms of the Creative Commons Attribution License, which permits unrestricted use, distribution, and reproduction in any medium, provided the original author and source are credited.

\begin{abstract}
The oases of the Draa are part of the biosphere reserve recognized by UNESCO, 2000. These oases are agro systems located in the Saharan region of southern Morocco. They are the main sources of livelihood of the indigenous population. The sustainability of the oasean system for centuries has made him a rich and resilient ecosystem. Despite its aridity and isolation, the population had always been able to adapt and optimize natural resources, which are scarce. However, during the last 50 years extreme events (droughts, floods and locust attacks) have become increasingly frequent, and have a considerable threat. The article is a diagnostic of resilience state and the impact of extreme events on food security and even existence of this heritage.
\end{abstract}

Keywords: Pre-sahara; Oasean model; Sustainability; Resilience

\section{Introduction}

The oasis can be defined as intensively cultivated areas in a desert environment that is strongly influenced by aridity [1]. Several stratums of cultures developed thanks to the favorable microclimate created by date palms. This is commonly called the oasis effect [2]. Oases have a long history, stretching some 6,000 years. The areas of Egypt Mesopotamia (Iraq) are the birthplace of the date palm [3]. Today, the oases are distributed throughout the arid areas of the world. We distinguish the new oasis in North America and Australia, and the oldest, throughout arid regions linking Africa to Asia [4]. In Morocco, there are 11 provinces phoenicicoles (Figuig, Errachidia, Ouarzazate, Tata, Tiznit, Guelmim, Tan Tan, Laayoune, Smara, Boujdour and Oued Ed-Dahab), located in the South and Southeast of the country, representing two-thirds of the national territory. They are limited to the north by the chain of the High Atlas, to the east by the MoroccanAlgerian border, to the south by the Moroccan-Mauritanian border and west by the Atlantic Ocean [5]. The major ones are the oasis of Tafilalet (Errachidia) and of the Draa Valley. Draa valley is a rural area characterized by an (irrigated) oasean agriculture, this oasis has been declared as «biosphere Reserve» by UNESCO in 2000, covering an approximate area of 7.2 million ha over the provinces of Errachidia, Ouarzazate, and Zagora [4]. Middle Draa valley oases occupy about 27,000 ha in six palm groves characterized by a vegetation management in stratum dominated by the date palm that promotes micro-hot and humid climate conducive to diversified agricultural production [6]. This canopy provides protection against the arid climate for the lower levels of fruit, tree crops such as Henna, grenadiers, gardening, and livestock fodder. "The local economy is dominated more than $70 \%$ by extensive agriculture and pastoralism, these activities are inefficient and do not always meet the daily needs [7]. Recognizing that food security is central in any region of the world, we emphasize the place of agricultural and livestock products in human nutrition, as principal sources of income in oasean communities.
The oases have adapted to harsh conditions for centuries and ensure the sustainability of this system. The oases, which now represent a real growth potential in seemingly hostile environments, are adaptive models and tools to fight against desertification [8]. Despite its importance, during the last 50 years extreme events (droughts, floods, and locust attacks) have become increasingly frequent, and have a considerable threat on this agro-system. In fact, the oasis currently faces new challenges like reduced production resulting from Bayoud disease, soil salinization, soil encroachment, water erosion and drought $[6,9]$. The oasis civilization, its lifestyle, and its special ecosystems are part of the common heritage of humanity: these threats could make them disappear within one or two generations [4]. Is this acceptable? Through this paper, we will prove or disprove this claim. We will diagnose the oases's resilience and the impact of extreme events on food security, and even the viability of this heritage, by a detailed spatiotemporal analysis.

In general, after Sabbari and Larbi [5], the oasean environment is characterized by:

- Low and irregular rainfall in time and space (between 50 and 200 $\mathrm{mm} /$ year);

- Very high in summer and relatively low temperatures in winter $\left(-5^{\circ} \mathrm{C}\right.$ to $\left.+45^{\circ} \mathrm{C}\right)$;

- A daily thermal amplitude generally quite high $\left(15\right.$ to $\left.20^{\circ} \mathrm{C}\right)$;

- An intense evaporation: in fact, it reached more than $2500 \mathrm{~mm}$ annually. Inside the palm, evaporation is reduced by micro-climate created by the arboreal stratum;

- Two types of winds in the North East and East that are dry and warm known Chergui.

\section{Potential of Oasean Ecosystems}

Because of its strategic position between the Sahara and the north of Morocco, and due to the importance of its resources, the Draa Valley has been highly attractive to people of various origins throughout its history [10]. Traditional agricultural techniques allow coping with low average values of precipitation together with a high variability by using a mixed system of irrigation agriculture and transhumant livestock 
grazing [11]. For centuries nomads and oasis communities have been demonstrating their adaptive capacities and resilience by coping with tough environmental conditions [9]. In fact, transhumant pastoralism mitigates variability in rainfall by mobility of herds on collective rangelands [12]. The access to collective lands used by tribal and intertribal groups as well as the opening and closing dates of pastures are fixed by the pastoralists at a local level [13]. Oases are support production systems based on a learned association of crops and livestock of sheep and goat breeds known for their high prolificacy [14]. Legumes are predominant and highly complementary major contributors to increased fertility of soils, favorable to other cultures, and restrict the use of nitrogen fertilizers, which pollute groundwater [15]. Early agriculturalists were led to the installation of oasis by the availability of water resources. It is primarily in the valleys and Wadis he went to fetch water, where it was shallower. The oases installed along the southern piedmont of the Saharan Atlas receive periodic flooding waters used for irrigation [16].

The biodiversity in oasis is concentrated on the borders of large desert areas on planet [4]. In dry-land land-use systems is centered on the conservation, use, and optimization of moisture and organic matter in the soil. Biodiversity is carefully managed and nurtured to interface with hydrological and nutrient cycling and provide for ecosystem resilience, food security/diversity, and risk minimization [17]. Agro-biodiversity in oases is not only conservatory but also continuously produces new branches of living species [4].

\section{Agriculture adapted to dry land area}

The oasis economy is closely linked with the agricultural sector, which has been a form of adaptation for centuries [10]. Oases had over the centuries a model of adaptation to climate change by integrating the constraints of natural resource management.

Several studies were mentioned some aspects of adaptations of the oasean model cited in several studies $[8,10,18]$. We quote here some adaptation methods cited by RADDO [8] like:

- Intensive agriculture within the oasis associated with extensive livestock on large external pastoral spaces of oasis allowed constant fertility maintenance.

- The traditional gravity irrigation of surface water, with water sharing according to the needs of the plots.

- Rational use of space is an expertise of flood spreading allowing the cultivation of large areas in years with heavy precipitation or, on the contrary, to fall back on irrigated perimeters in the dry years.

- In many cases, a system of water collection of groundwater and gravity adduction as "Khettaras" or "Foggaras", to cultivated areas from several kilometers.

- Development of an adapted biodiversity as a genetic reservoir of local species necessary to adapt to climate changes.

Traditional oasis consists of the superposition of three stratums:

- Stratum of trees: date palm 15 to $30 \mathrm{~m}$.,

- The shrub stratum: fruits such as apples, pomegranates and henna and,

- The herbaceous stratum: market gardening oasis with many varieties.

In fact, the oasis contains an important source of species and varieties of highly endemic fruits-grapes, peaches, apricots, pomegranates, dates, figs-in addition to cereals and legumes (barley, wheat, alfalfa)and animals (poultry, goats and sheep) among these D'man race (southern sheep race of the Moroccan oases) [4]. The palm trees are considered as umbrellas that offer various crops underneath a favorable microclimate for their development [10].

The population is concentrated in villages and 'ksours' (traditional agglomeration in oasean system) located outside the oasis. They settled in elevation on the edges of the alluvial terraces probably for defense and surveillance [19]. The date has always been, from time immemorial, a very important component of diet for both humans and animals in all countries of the southern and eastern Mediterranean [20]. Despite the severe climate, the farmer oasis has significant advantages, particularly plant and animal material quality with good adaptation to difficult conditions [5]:

- High productivity of certain local products (Cereals: Fartas, Cheguira, forage alfalfa, Filalie, etc.).

- Precocity of production (fruits, vegetables and cereals).

- Exceptional Characteristics of the ovine race (D'man race).

Considering the severe environmental constraints (unreliable water supply, high temperatures, soil salinity), wheat oases (called "Béldias" varieties) are likely to be veritable models for the study of the physiological bases of adaptation to the constraints of the dry land. These wheats of Sahara could, for the same reasons, be interesting spawners in the creation of varieties for the surrounding semi-arid areas [21]. Ducellier [22] was the first to draw the attention of agronomists to the originality of Saharan wheat and the cultural opportunities of the real importance that offered these cereals. With the significant reduction in the number of male palms, the oasean farmers have used artificial pollination locally called "Dokkar". This method has been used since Mesopotamian and Egyptian agriculture started using it thousands of years before our era [21].

In terms of livestock and animal power, it is well established that livestock have an important part to play as they provide food security and regular income; and the indigenous population have used this source since the creation of the oases. Animals of the oasis are used for the production of organic manure to fertilize the soil, already less fertile, and also used as a labor force. The ovine animals, mostly the 'D'mane' race, is particularly adapted to climatic hazards with "elastic" character known for its high prolificacy $(220 \%)$ and the ability to dual lambing [5]. In the oasis economy, livestock in general and sheep in particular are an adaptation strategy [10] intended for consumption, and cash flow. The camel is one of the species well adapted to the bioclimatic conditions of the Sahara. It offers milk, meat, wool, and leather, and locals use it for the transportation [11]. There are many sources of feed in the oasis, either as forage or from by-products of food crops [23].

\section{Water management}

Located in pre-Saharan regions, the oases suffer from severe aridity and scarcity of water resources. The largest part of surface water comes from the High Atlas Mountains, while the use of groundwater resources is provided by digging wells. The ancestral populations have shown a major form of adaptation to aridity constraints through the development of knowledge and heuristic expertise on a traditional water supply system called 'Khettara' [24] (Figure 1). 
Page 3 of 9

Where water is scarce regulating the use of water is more complex and detailed. Roman and Arab civilizations were able to rationally distribute and use water in diverse and ingenious ways [25] (Figure 2).

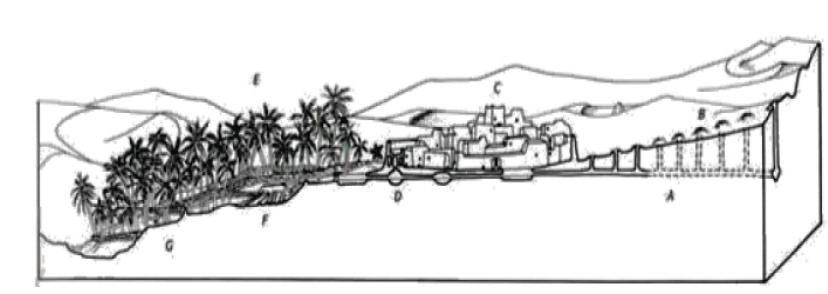

Figure 1: Khettara system. Water produced in the underground tunnel of the khettara (A), which is visible thanks to the vertical excavation shafts (B), runs beneath the habitat (C), and gathers in decantation tanks (D) useful for drinking water, ablutions and for cooling the dwellings. Once conveyed in open air channels (F), water irrigates the palm grove (E) subdivided into tilled parcels by low mud walls (G). Source: http://www.hydriaproject.net/

In 1888, Ch De Foucauld reported that the Draa region (the study area) was very rich in terms of water resources and biomass. The following paragraph is an extract from his report on this area (1888):

All Draa has the same enchanting look: same freshness everywhere, same abundance of water, same lush vegetation. However, there is no place where water is never dried up in the river: in some summers, parts of its basin dry up, but the years when this happens are rare. Even then, the channels that serve to feed and water the Draa do not cease to flow at full edges. In the Draa, floods are more frequent then droughts. It is not uncommon to see in winter the river flooding the whole valley even till the walls of the Ksars. The water from the Oued Draa, even of it is a little yellow, it is pleasant to drink. Among the countless trees that shade the river, palm trees dominate everywhere... there was a large quantity of fruit trees, figs, pomegranates, peaches, grapes and so on. ... Throughout the Draa country, bees are numerous and honey is abound"... Ch De Foucauld 1888: 286. Cited by Ait Hamza et al. [10].

\section{Micro-climate enabling}

The oasis effect is an internal microclimate created under the influence of sunlight filtering through the palm, moisture, heat and light; it is very suitable for agriculture and livestock [4]. The characteristic insularity of the oasis, environed by the desert, precludes surrounding refuge vegetation, which acts as a reservoir in other regions, especially for auxiliary insects [26]. The oasis also plays another physical role. It is a protective role against the effects of wind in conditions of sufficient density respecting the space devoted to intercropping [15]. For the traditional oasis, several vegetation strata, interception of solar radiation will increase the cooling near the soil [2]. The soil is generally alluvial and little evolved with an alkaline trend. It has, in places, high levels of salinity [5]. As the main tree of the oasis and unlike many other plants, the palm tree can support up to $30 \mathrm{~g}$ of salt per liter of water - water in arid regions often contains high levels of minerals such as salt - but with some decrease in production [4]. These strengths have enabled the people of the oasis to adapt to the harsh climatic conditions, scarcity of water resources, and low soil quality in order to adopt appropriate means of production.

Agriculture and farming are the main economic activities in the area. Agricultural development might provide economic development; through the increase of agricultural land and improvement of productivity there will be, subsequently, assurance of food security. Date palms can help ensure that food security. The date palm is used as food for humans and even livestock. In fact, it is the main source of income for the community oasis, as the finished product and also as byproducts. Unfortunately, for the past 50 years, the impact of climate change and human intervention has changed the dynamics of this system, which has become vulnerable.

\section{Environmental Vulnerability and the Impact of Climate Change}

The number of palm trees in the world can be estimated at 100 million trees. The yield per hectare is variable: 9 tons and 1.2 tons in Egypt to Morocco [27]. Recent indirect drivers of change in the Maghrebian oasis (on the northern border of the Sahara) have been population increase, policies to settle nomadic populations, investments generated by migrants working abroad, and transformation of self-sufficiency to open-market economies in countries of the [28]. Consequently, in Draa Valley, altogether over 1.4 million date palms can be found in the region. But from a number of over 15 million palm trees at the beginning of the 20th century, the situation has changed drastically due to a specific palm tree illness called Bayoud, water stress, and the aggradation of sand from the Sahara Desert [29]. The main forms and degradation processes that affect the oasis agro-system are presented as follows:

\section{Salinity and desertification}

The strong hot winds and high temperatures accelerate the evaporation rate which encourages increasing salinity of the soil in this region (Table 1). The salinity causes a $35 \%$ decrease of total agricultural profits; passing from 189.6 MDH (22,9USD) without salinity to $119.4 \mathrm{MDH}(14,4 \mathrm{USD})$ with salinity; based on the value $(\mathrm{USD} / \mathrm{MAD}=0.12108)$.

\begin{tabular}{|l|l|l|l|l|l|l|}
\hline & \multicolumn{2}{l|}{ Without salinity } & \multicolumn{2}{l|}{ With salinity } \\
\hline & Normal & Medium & Low & Normal & Medium & Low \\
\hline Total water use $\left(\mathrm{Mm}^{3}\right)$ & 233.8 & 186.6 & 98.7 & 218.0 & 137.6 & 29.6 \\
\hline Use of available crop area (\%) & 63.9 & 50.7 & 26.0 & 47.7 & 32.0 & 6.1 \\
\hline Agric. Profits total (MDH) & 260.4 & 189.6 & 79.6 & 171.0 & 119.4 & 20.5 \\
\hline
\end{tabular}

Table 1: Basin-wide simulation results for normal, medium and low water availability without and including salinity effects [30]. 
When water scarcity alone is taken into account, farmers will probably decrease crop areas, but also crop yields to a minor extent to deal with the scarcity situation. But in a situation [30] which combines water scarcity and high salinity of the water available, farmers face a more complicated dilemma, as a reduction of the amount of irrigation water per hectare as in the scenario without salinity would swiftly increase soil salinity and depress yields by far more [30].

In the last decade; $93 \%$ of Moroccan territory is affected by desertification [31], and the province of Zagora (Middle Draa Valley) is considered among the most barren of the country [32]. The problem of silting became threatening from the 1970s. This threatens homes, farmland, irrigation canals and road infrastructure in the palm groves [14]. Advancing sands constitute a real threat for the poor rural population [10] Today, the Services of Agriculture, and those of Waters and Forests must be constantly mobilized against salinisation and sand that invade palm groves, mainly those located downstream (M'hamid, Ktaoua and Fezouata) [10]. In the Draa Valley, 20\% of modern and traditional irrigation networks are sanded to varying degrees [33].

\section{Bayoud desease}

The 'bayoud' is a fungus (Fusarium oxysporum f. sp. albedinis) which attacks mainly palm trees. The fungus enters the tree by its roots and causes death once it and its toxins reach their terminal bud [10]. This is the most serious disease of the date palm. In Morocco, 10 to 12 million trees have been destroyed in a century and two varieties marketed have virtually disappeared [34]. Thus the phytosanitary status of the oasis is constantly threatened by introductions of pests and diseases which are largely from import of plants [35].

\section{Local varieties and unsustainable crops introduced}

The oasis areas, have suffered, like other regions, strong genetic erosion due to the introduction of new, varieties. Some local varieties may disappear completely in a few years if they are not carefully collected and stored [27]. To genetic erosion is added to the introduction and expansion of unsustainable cultures especially like watermelon. Cultivation of henna or watermelon in the dry season seems absurd and unsustainable. Pumps spit huge amounts of water to irrigate the crops at this time, knowing that the groundwater level continues to decline. Farmers switch to more profitable crops but this practice is harmful in the long run, especially the cultivation of watermelons which exacerbates the demand for water [6]. In fact, from 2012 to 2013 the area of watermelon cultivation almost doubled (670 in 2012 to 1130 in 2013) [36].

\section{Impact of drought on water availability, yield and livestock}

Saharan and pre-Saharan regions are subjected to periods of drought that may last several years and cause considerable losses both by falling production and by the dying of trees [37]. Table 2 shows the impact of drought on potential resources: the surface water resources decrease from $225 \mathrm{Mm}^{3}$ in an average year to $102 \mathrm{Mm}^{3}$ in a dry year.

\begin{tabular}{|l|l|l|l|l|}
\hline & Average Year & \multicolumn{2}{l|}{ Dry Year } \\
\hline Potential resources & $\mathrm{Mm}^{3}$ & $\%$ & $\mathrm{Mm}^{3}$ & $\%$ \\
\hline Surface water resources (Draa and tributaries) & 225 & 85 & 102 & 56 \\
\hline Extracted groundwater resources & 40 & 15 & 80 & 44 \\
\hline Total exploited resources & 265 & 100 & 230 & 100 \\
\hline
\end{tabular}

Table 2: Potentiel de la zone en ressources hydriques. (Source: Cited by Heidecke [30]).

The impact on water resources is seen especially on yield. In fact, on average, palm trees can yield $18 \mathrm{~kg}$ of dates per tree in the southern regions of Morocco [29].

Yields of date palms, measured in kilograms per tree, are highly correlated to the amount of available surface water [30]. Production strategies are strongly related to climatic conditions. Water stress caused by drought and salinity is the most important abiotic factor limiting plant growth and crop productivity in arid lands [39]. Therefore, enhancing osmotic stress tolerance in crops grown under such conditions could provide a solution to this problem [40]. In Draa valley, the agricultural sector is a key to economic development. This valley is mainly rural and its economy remains highly dependent on irrigated agriculture [41]. Although agriculture is essential to provide sustenance [42], the droughts in the Draa Valley have consequences on agricultural yields, causing low income and poverty in rural areas.

Regarding the livestock, it is not only a source of income, but also plays a role in food supply. A high number of cattle, sheep, and goats assure meat consumption for a large part of the local population [30] (Figure 2).

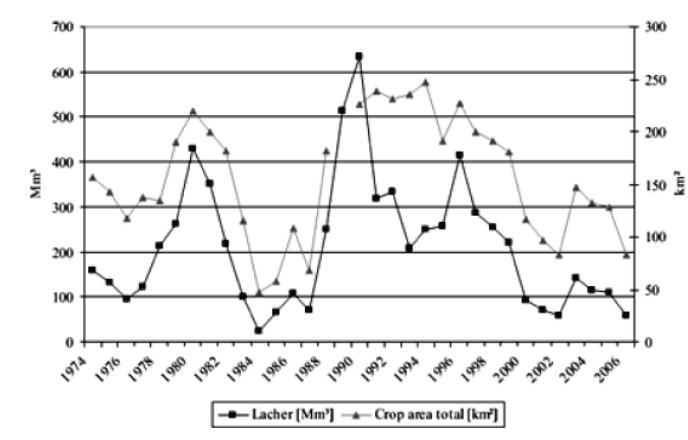

Figure 2: Relation of water availability and area cultivated from 1974 to 2006 [38].

In the Draa oases, a smaller number of livestock is kept near houses which profit from fodder cultivated in the oases, namely alfalfa, barley, dates, maize, but also leftovers of food from the house [43]. Livestock can also be affected by climate change. Specifically, livestock can be 
Page 5 of 9

affected in 2 ways: the quality and amount of forage from grasslands and direct effects on livestock due to higher temperatures [44].

There is evidence that intensively managed livestock systems are potentially more adaptable to climate change than crop systems because they are better able to adapt to extreme events [44]. In the Middle Draa Valley, the decrease is more severe for all animals as precipitation and hence fodder availability is weaker in the area [30].

According to Figure 3, the number of animals depends on the precipitation variability. This is mainly due to the latent water stress of plants. Livestock is an important income source for families in the Draa region [46]. During drought years, the number of animals is reduced due to fodder shortages.

In the past 50 years, the oasis has experienced many disruptions caused by droughts, more severe salinity, siltation, the "Bayoud" disease, overgrazing of natural vegetation and excessive harvesting of woody vegetation. The combined actions of these factors have gradually degraded the oasis, and have made it now reliant on financial transfers by migrants. The Environmental vulnerability has radically changed the socio-economic situation. In general, agricultural income of farmers in oasis is steadily declining [4].

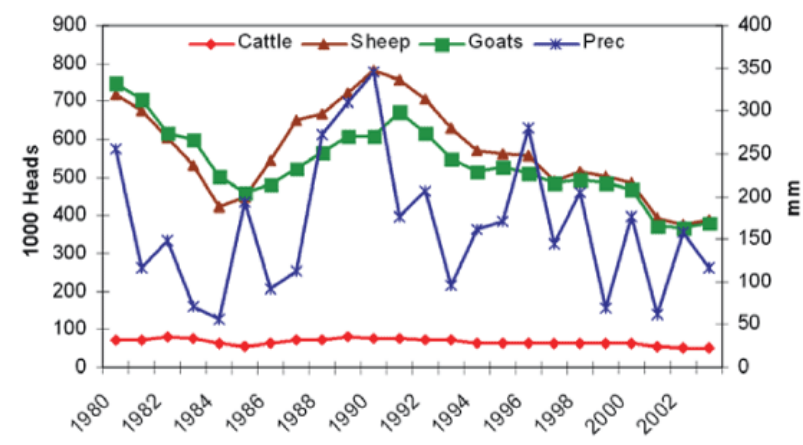

Figure 3: Number of animals in the Draa region from 1980 to 2003. Source: ORMVAO [45].

Table 3 shows that farmers recorded a margin negative due to high amount of costs (Labor, Seeds, Irrigation...).

\begin{tabular}{|l|l|l|}
\hline Charges & $\begin{array}{l}\text { Total costs from survey } \\
\text { dh/ha }\end{array}$ & Total costs US \$/ha \\
\hline Total costs & 7123 & 854,76 \\
\hline Total revenues & 3472 & 416,64 \\
\hline Gross margin & -3651 & $-438,12$ \\
\hline
\end{tabular}

Table 3: Gross margin of wheat per ha in the Draa valley in 2005 [30]. Note: 1 US $\$=8.26 ; 1 \mathrm{MAD}=0.12$ US $\$$; www.oanda.com; Sept. 28, 2013.

Otherwise as already mentioned before, soils in the Middle Draa Valley are little developed which cause lower crop yields. Moreover, tourism is a growing but limited sector, but declining agriculture and the absence of industry offer only a few jobs for the increasing population. These problems drive people to leave their areas for migrating, predominantly out of the Draa Valley, is common to support families left behind [47]. In fact, $65 \%$ of households in the
Draa valley depend on remittances from migrants [48]. Oases communities of Middle Draa valley are geographically at the periphery they often live in remote and isolated areas on ecologically fragile land which increases their exposure and vulnerability to climatic events. In human terms, these oases housed about 240000 of inhabitants in 2004, $85 \%$ of the rural population of the region (Table 4 ).

\begin{tabular}{|l|l|l|}
\hline & Urban area & Rural area \\
\hline Population & 42802 & 240566 \\
\hline Illiteracy & $34.75 \%$ & $55 \%$ \\
\hline Rate of access to drinking water & $86 \%$ & $63 \%$ \\
\hline Poverty rate & $12.75 \%$ & $37.64 \%$ \\
\hline
\end{tabular}

Table 4: Social aspects of Middle Draa Valley [33].

All these factors contribute to accelerate poverty in rural areas and the reliance of the poorest on fragile ecosystems. Environmental vulnerability is much greater in from upstream to downstream of the Middle Draa Valley [6] which means that the socio-economic problems are more pronounced downstream than upstream. In fact, M'hamid (rural area in most downstream) passed from 8671 to 7764 inhabitants and Ktaoua ( $40 \mathrm{~km}$ to upstream of M'hamid) from 24780 to 17553 inhabitants, with a loss of 907 and 7227 inhabitants respectively [49]. The indexes of fertility in the year 2004 (3.4 for Ktaoua and 2.9 for M'hamid) show that the rate of natural increase is still very high [11]. migrants are used to "subsidize" pastoral activities [48]. Drought and desertification have a negative impact on water availability and quality, which have damaged the agriculturally based economy of the region. In addition the quantity and quality of domestic water has decreased. Apart from the indirect economic consequences, increasing migration, the direct negative impacts of the water crisis can be seen in the areas of nutrition, hygiene, and quality of life [48].

\section{Future trends based on water resources}

This section, looks to the future. It reviews the drivers that have changed and what the implications will be for agricultural products and livestock contributing to food security in the dryland area, specially the oasean community.

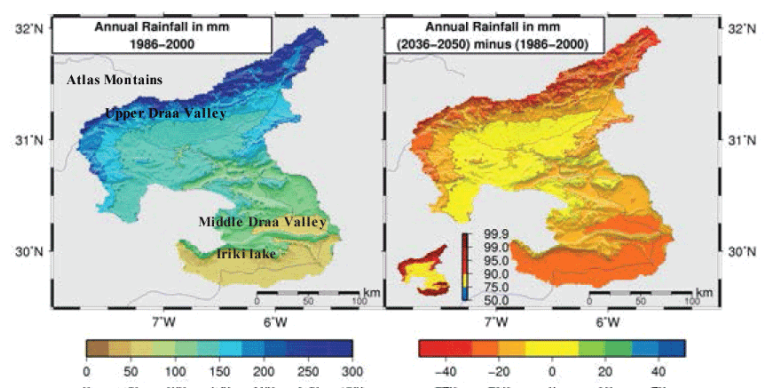

Figure 4: Annual mean rainfall $1986-2000$ in $\mathrm{mm}$ (left) and the difference between the periods (2036-2050) minus (1986-2000). The small map in the right panel shows the significance of the climate change signal, [50]. 
Page 6 of 9

The existence of the oasis is due to the presence of water resources, in this section we will focus on the future situation in relation to water resources.
The Draa Valley (Upper and Middle presents a spatial contrast of precipitation between upstream (High Atlas) and downstream Sahara (Iriki) let's say that this gradient follows the topography (Figure 4).

\begin{tabular}{|l|l|l|}
\hline & $\mathbf{2 0 1 0}$ & $\mathbf{2 0 2 0}$ \\
\hline Reference scenario (Million m3) & 76 & 113 \\
\hline Climate change B2 (Million m3) & 76 & 144 \\
\hline Climate change A2 (Million m3) & 76 & 183 \\
\hline
\end{tabular}

Table 5: Water demand under climate change B2 and A2 Scenarios for the Ternata palm grove (In Middle Draa Valley). All months in Million Cubic Meters [51].

The study projected locally shows a tendency towards dryness and reduced precipitation will increase the water crisis in the region and beyond will impact the food security. In order to predict water demand of the Middle Draa Valley, we used trends of water demand developed by [51] using the WEAP model (Water Evaluation and planning System), created by Stockholm Environment Institute (SEI). This model allows an analysis of the water demand under climatic and socio-economic scenarios, for the agricultural districts of Middle Draa Valley. We present here, the water demand of the palm grove of Ternata, the most important of the Middle Draa Valley oases. The model predicts an increase in water demand (Table 5) in Ternata palm grove under the two IPCC greenhouse gases scenarios (A2 and B2).

Through this table, we see that under A2 scenario, in the coming years, the water demand will be more important than under B2 scenario. In fact, under A2, the demand in 2010 was 76 Million meter cubic (MMC), and will be about 183 MMC by 2020 , whereas, under B2 will be 144 MMC.

In fact, climate change alters the hydrological regime and accelerates the land degradation of MDV and thereafter influencing agricultural production. Vulnerability is exacerbated by population growth, as well as poor standards for health, education, and governance [52]. The main water resources of middle Draa Valley (palm groves or palm oases) are Mansour Eddahbi dam in upstream and groundwater. The hydrology of the MDV is controlled by releases of Mansour Eddahbi dam which was constructed in 1972 with an initial capacity of 583 million $\mathrm{m}^{3}[6,53]$.
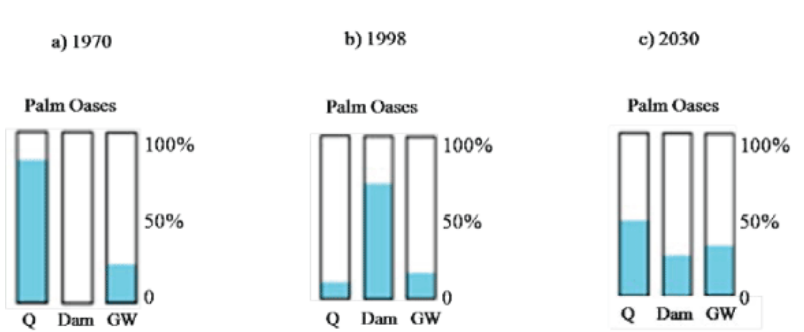

Figure 5: relative water use in Draa for a) pre-dam conditions, b) post-dam conditions and c) future scenario. $Q=$ discharge, dam= Mansour Eddahbi dam, GW=Groundwater (based pn direction de la recherché and Minstère des Travaux Publiques (1998) and Minstère de l'Equipement (2002), [54].

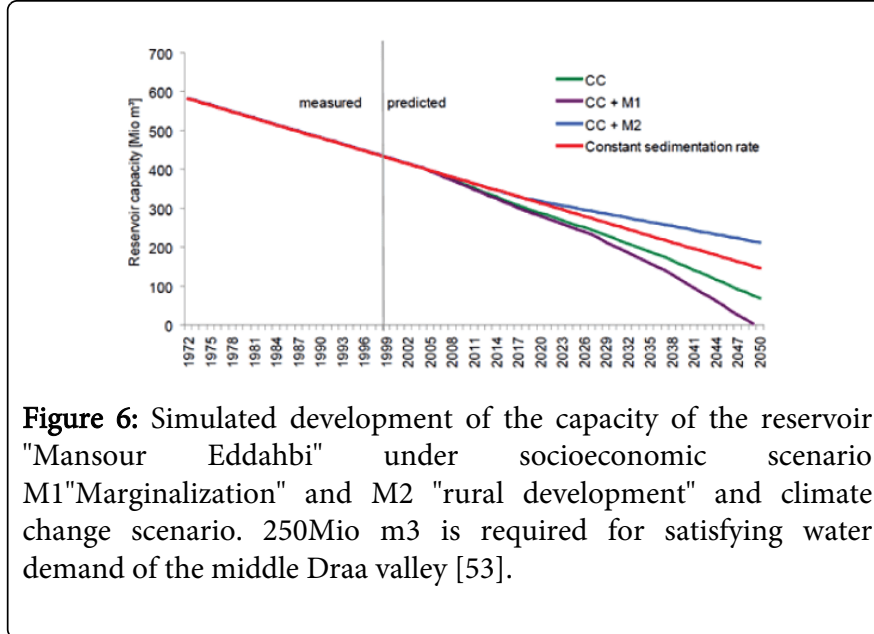

As showed in Figure 5, before the Mansour Eddahbi dam was built in upstream of Middle Draa Valley (1970), irrigation was mainly dependant on river discharge $(\mathrm{G})$ and groundwater extraction $(\mathrm{GW})$. After the dam was built (1998), the palm groves of Middle Draa Valley became dependant on dam water use.

In 2030, if the rapid infill of dam due to high sediment transport rates in rivers continues at the present rate the dam will no longer be fully functional for irrigation [54]. In fact, the Mansour Eddahbi dam experienced a number of problems which include siltation [9]. Indeed, the capacity was reduced by approximately $25 \%$ to $438 \mathrm{Mm}^{3}$ (in 1998) due to siltation; this corresponds to a mean erosion rate of 5,6t/ha/year [53]. According to forecasts (Figure 6), the dam would hold less water in the future under different scenarios.

As mentioned above, agriculture is a major activity in the Draa region, which means that, water scarcity is a principal problem. During the drought period, farmers substitute surface water by groundwater. Groundwater on the other hand is more saline which leads to decreasing crops yields [55]. The changes have affected crops and livestock in a number of ways resulting in reduced productivity. It is necessary to gather the resources necessary to improve crop yields by introducing routes more efficient techniques that provide better profitability. Traditional oasis is less and less productive and modern plantations are often based on farming systems that are fragile and present a high economic and ecological risk [56]. But, the nature of the biophysical and the human responses to them are complex. We recommend alternatives for development assistance strategies to 
increase the benefits that can generate small tanks and participatory irrigation management.

They include crop diversification of agricultural production to improve benefits and have greater participation and better interactions between farmers and planers. The oases of the Middle Draa valley are characterized by the fragility of the "natural environment". Oases are a model for efficient resource-management for the whole planet; they can become a new model for development and economy through the actions undertaken to safeguard and value them [57].

\section{Conclusion}

Dryland and oasis communities in developing countries are considered to be among the most threatened by climate change impacts and the consequences of increasing human pressure on the environment [9]. Drought and desertification have a negative impact on water availability and quality, which have damaged the agriculturally based economy of the region. In addition the quantity and quality of domestic water has decreased. Succession of dry periods, 'Bayoud' disease, water and soil salinization, desertification and dam silting, were key stressors on environment and ecosystems groves of the Middle Draa Valley.

The actual annual rate of growth of the population is very high (3\% mainly due to a relative improvement of hygiene conditions and food and the precocity of marital unions [5]. The palm is the originality of this region. The preservation and restoration of the palm are a condition for the advancement and success of any project. The rehabilitation of the palm through a number of crucial actions:

- Solve the problem of soil salinization

- Improve drip irrigation

- Use cultural practices that consume less water

- Improving the management of natural resources

- Improving the living conditions of the populations concerned while diversifying their income sources to relieve the pressure on natural resources.

Agriculture in the Draa region is mostly for subsistence and local consumption; marketable products play a minor role. One exception is the production of dates, which generate additional income. Most farmers cultivate similar crop mixes consisting of alfalfa, cereals (sweet corn, barley, maize), henna (in the south) vegetables (tomato, potatoes, onion, beetroot), fruit trees and date palms [58]. Agricultural activity is an essential source of life for the majority of the population and most of the arable land is plowed regularly. The date palm is confirmed as a fitting quality of the ecosystem oasis. Forage crops provide the basis for fertilization and coexist with the palm in good conditions. Food crops and cash crops are in turn competing and complementary to the soles, according to fluctuating demand markets, their distribution and size are dependent on the availability and cost of labor [15], there are so many things to learn from her fruit, diet fibers, strips, spathe, fins, trunk, stem, leaflets, nothing is lost. Nowadays, traditional agriculture food became totally incompatible with modernization lifestyle. The impact of climate change is seen in these areas especially on water resources and on agriculture, the main economic resource in the oases region, which makes the region very vulnerable and adaptation is related to water management. To do this, in the Middle Draa Valley, the flood-driven natural system has been replaced by a human controlled flow regime, since the reservoir Mansour-Eddahbi went into service [58].The region ", a soil fungus that attacks the best varieties of date palm. What aggravates the situation is the orientation of farmers to more profitable crops but harmful in the long run, especially the cultivation of watermelons which dramatizes the demand for water [6]. In the 70's, water for irrigation was mainly drawn from the Draa River, but during the last decades, irrigation with surface water has been increasingly supplemented or substituted by irrigation with groundwater by farmers in the MDV [30]. In 1990, the IPCC noted that the greatest impact of climate change would be on human migration. This is became the most common strategy of survival in the oasis and the remittances enabled villager's o finance local agriculture and modern irrigation tools [58]. The exceptional genetic resources (current), is an unrecognized wealth may eventually diminish, regress and even disappear [3].

\section{References}

1. DSA (1989) Les Cahiers de la Recherche Développement, no 22 (juin 1989) du périodique du DSA.

2. Riou C (1990) Bioclimatologie des oasis, Options Méditerranéennes, Sér. $\mathrm{A} / \mathrm{n}^{\circ} 11$ - Les systèmes agricoles oasiens.

3. Peyron G, Gay F, Ali Rafat A (1990) Phoenologie du palmier dattier, Contribution à l'étude du patrimoine génétique phoenicicole en Egypte, Options Méditerranéennes, Sér. A 1 (11).

4. NovaTerra (2009) En vie d'oasis Découverte de mondes et modes de vie menaces, Montpellier-France.

5. Sabbari H, Larbi (1988) Les zones phoenicicoles marocaines, Communication présentée au Séminaire sur, Les systèmes agricoles oasiens Tozeur (Tunisie).

6. Karmaoui A, Messouli M, Yacoubi Khebiza M, Ifaadassan I (2014a) Environmental Vulnerability to Climate Change and Anthropogenic Impacts in Dryland, (Pilot Study: Middle Draa Valley, South Morocco). J Earth Sci Clim Change S11: 002. 2014.

7. Reichert (2008) Introduction into the Draa catchment. International conferences in Ouagadougou, Burkina Faso, 2008. Global change and water resources in west africa. the German-african GLOWA projects.

8. RADDO (2011) Lutte Contre La Désertification, Les Oasis Au Péril Du Changement Climatique, Le réseau d'associations oasiennes du Maghreb (RADDO) (www.raddo.org).

9. Chelleri L, Minucci G, Ruiz A, Karmaoui A (2014) Responses to Drought and Desertification in the Moroccan Drâa Valley Region, Resilience at the Expense of Sustainability? The International Journal of Climate Change: Impacts and Responses 5: 1835-7156.

10. Ait Hamza M, El Faskaoui B, Fermin A (2009) Migration and environmental change in Morocco: The case of rural oasis villages in the Middle Drâa Valley, Responsible Institution: Erasmus University Rotterdam (EUR). 044468. EACH-FOR.

11. Barrow CJ, Hicham H (2000) Two complimentary and integrated land uses of the western High Atlas Mountains, Morocco: The potential for sustainable rural livelihoods, Applied Geography 20: 369-394.

12. Freier, Korbinian Peter (2011) Modelling alternative land-use regimes in semi-arid Morocco, University of Hamburg, Hamburg.

13. Rössler M, Kirscht H, Rademacher C, Platt S (2010a) Demographic development in Southern Morocco: Migration, urbanization, and the role of institutions in resource management, Impacts of Global Change on the Hydrological Cycle in West and Northwest Africa (eds. Speth P, Christoph M, Diekkrüger B), Springer, Heidelberg, Germany.

14. Laouina A (2006) Prospective Maroc 2030, Gestion durable des ressources naturelles et de la biodiversité au Maroc, Haut commissariat au plan.

15. Ferry M, Toutain G (1990) Concurrence et complémentarité des espèces végétales dans les oasis, Options Méditerranéennes, Sér. A/nº 11 - Les systèmes agricoles oasiens. CI901501. 
16. Bouzaher A (1990) Note technique: Création d'oasis en Algérie, CIHEAM - Options Méditerranéennes, CI901507.

17. UNESCO (2005) Combating desertification traditional knowledge and modern technology for the sustainable management of dryland ecosystems, Proceedings of the international workshop elista, republic of kalmykia, russian federation, UNESCO-MAB Drylands Series No. 4.

18. Ouhajou L (1996) Espace hydraulique et société au Maroc: Cas des systèmes d'irrigation dans la vallée du Dra Agadir: Universtité Ibn Zohr, Facultés des Lettres et des Sciences humaines, Série thèses et mémoires $n$ ${ }^{\circ} 7$.

19. Toutain G (1979) Une approche globale : l'écosystème saharien mise en valeur des oasis à palmeraies dattières.

20. Estanove P (1990) Note technique Valorisation de la date, Options Méditerranéennes, Sér. A/ $n^{\circ} 11$ - Les systèmes agricoles oasiens.

21. Benlaghlid M, Bouattoura N, Philippe Monneveux et Christiane Borries (1990) Les blés des oasis: Etude de la diversité génétique et de la physiologie de l'adaptation au milieu, Options Méditerranéennes, Sér. A/ n) 11 .

22. Ducellier L (1920) Les blés du Sahara, Alger, 56 p.

23. Tisserand JL (1990) Les ressources alimentaires pour le bétail, Options Méditerranéennes, Sér. A/ nº11-Les systèmes agricoles oasiens.

24. Benqlilou H, Bensaid S (2013) Protection and performance of the ancestral water supply system 'Khettara' as a sustainable alternative for arid regions, Water Science \& Technology: Water Supply 13: 1452-1462.

25. Charoy J, Torrent H (1990) Origine, gestion de l'eau, évaluation des aquifères dans les oasis, Options Méditerranéennes, Sér. A / n 11, -Les systèmes agricoles oasiens. CI901498. 1990.

26. Brun J (1990) Equilibre écologique et lutte biologique. Les ravageurs du palmier dattier. Les moyens de lutte contre la cochenille blanche (Parlatoria blanchardi TARG), Options Méditerranéennes, Sér. A/ nº 1l, 1990 - Les systèmes agricoles oasiens. CI901502.

27. Ben Abdallah A, (1990) La phoeniciculture. Options Méditerranéennes, Sér. $A / n^{\circ} 11$ - Les systèmes agricoles oasiens

28. Safriel UN, Adeel Z, Niemeijer D, Puigdefabres J, White R, Lal R, Winslow M, Ziedler J, Prince S, Archer E, King C (2005) Dryland systems. In: Hassan R, Scholes R, Ash N (Eds.) Ecosystems and human well-being: Current state and trends, Washington, Covelo, London: 623-662.

29. ORMVAO (2003b) Journée d'information sur la réserve de biosphère des oasis de Sud Marocaine, Ouarzazate.

30. Heidecke, 2009. Economic analysis of water use and management in the Middle Draa Valley in Morocco. Vorgelegt am 22. page 16-25. 2009.

31. Badraoui M (2005) La convention des Nations Unies sur la lutte contre la désertification dans les pays gravement touches par la sécheresse/ou la désertification, en particulier en Afrique, P. I. Rabat: Institut agronomique et vétérinaire Hassan II.

32. Harakat I (2007) Les acteurs de la coopération et la dimension socioéconomique de la désertification dans le sud du Maroc: cas de Zagora, Mémoire de maitrise en science politique, Université du Québec Montreal.

33. EVICC (2011) Evaluation de la vulnérabilité et des impacts du changement climatique dans les oasis du Maroc et structuration de stratégies territoriales d'adaptation, Mission 1.1 : Bilan-Diagnostic des vulnérabilités climatiques et des capacités d'adaptation en situation actuelle. Rapport complémentaire.

34. Bounaga N, Djerbi M (1990) Pathologie du palmier dattier, CIHEAM Options Méditerranéennes, Sér. A/ n 11, 1990 - Les systèmes agricoles oasiens.

35. Toutain G (1977) Élément d'Agronomie saharienne, De la recherche au développement, $277 \mathrm{p}$,

36. ORMVAO (2013) Office Régional de Mise en Valeur Agricole d'Ouarzazate, ORMVAO, Bilans des activités de 2013 de l'office régional de mise en valeur agricole de Ouarzazate.
37. Hajjaji A (1990) Arboriculture, cultures maraîchères et de rente en zones oasiennes, Options Méditerranéennes, Sér. A/ $\mathrm{n}^{\circ}$ 11- les systèmes agricoles oasiens.

38. ORMVAO (2003c) Rapport d'activité exercice: 1978-2003. Ouarzazate.Morocco.

39. El-Beltagy, Adel, Magdy Madkour (2012) Impact of climate change on arid lands agriculture, Agriculture \& Food Security 1.3.

40. Madkour M (2003) Biotechnology and its application in agriculture and food production: the Egyptian experience, Biotechnology and sustainable development: Voices from the South and NorthWallingford, UK: CABI publishing; 55-66.

41. Graf K (2010) Drinking water supply in the Middle Draa Valley, South Morocco, Options for action in the context of water scaricity and institutional constraints.

42. Roth A (2008) Agricultural Structure in Ouled Yaoub, IMPETUS Atlas Morocco. Research Results 2000-2007. 3. University of Bonn, Germany. 978-3-9810311-6-4.

43. ORMVAO (1981) Etablissement d'un plan directeur de mise en valeur agricole de la vallée du Draa moyen. Ouarzazate.

44. Adams RM, Hurd BH, Lenhart S, Leary N (1998) Effects of global climate change on agriculture: an interpretative review. Climate Research 11: 19-30.

45. ORMVAO (2003a), Rapport sur les palmerais, Ouarzazate.

46. Heidecke C, Roth A (2008) Drought Effects on Livestock Husbandry,

47. Rademacher C (2008) Work Destinations of Ouled Yaoub Labour Migrants, Atlas IMPETUS.

48. Rössler M, Kirscht H, Rademacher C, Platt S, Kemmerling B, Linstädter A (2010b) Migration and resource management in the Drâa Valley, Southern Morocco. In: Impacts of Global Change on the Hydrological Cycle in West and Northwest Africa (eds. Speth P, Christoph M, Diekkrüger B), Springer, Heidelberg, Germany.

49. RGPH (2004) Recensement Général de la Population et de l'Habitat. Haut commissariat au plan du Maroc. 2004.

50. Born K, Piecha K, Fink A (2008) Shifting Climate Zones in the Northwestern Maghreb, In: IMPETUS Atlas Marokko - Research Results 2000-2007 (eds. Schulz O, Judex M), IMPETUS Project, Köln/Cologne.

51. Karmaoui A, Messouli M, Yacoubi Khebiza M, Ifaadassan I (2014b) Impact of climate change on water resources in the oases of Middle Draa Valley, South east of Morocco, Fourth Conference on Climate Change and Development in Africa (CCDA-IV) Africa Can Feed Africa Now: Translating Climate Knowledge into Action, October 8-10, 2014, Marrakech, Morocco.

52. Field, Christopher B, ed (2012) Managing the risks of extreme events and disasters to advance climate change adaptation: Special report of the intergovernmental panel on climate change. Cambridge University Press.

53. Diekkruger B (2010) Impact of global change on hydrology and soil degradation-scenario analysis for semi-aride Draa catchment (south Morocco) Conference of global catchment initiative (GCI). University club Bonn, Germany.

54. De Jong C, Makroum K, Leavesley G (2006) Developing an oasis-based irrigation management tool for a large semi-arid mountainous catchment in Morocco, In : Proceedings of the iEMSs Third Biennial Meeting: Summit on Environmental Modelling and Software, International Environmental Modelling and Software Society, Burlington, USA.

55. Goldbach H, Hecklelei, Kuhn, Heidecke, Abdelrazek, Gresens, Roth, et al. (2008) ricultural production and income security under increasing water uncertainty in Draa valley, International conferences in Ouagadougou. Burkina Faso, 2008. Global change and water resources in west africa. The German-African GLOWA projects.

56. Ferry M (1995) La crise du secteur phoenicicole dans les pays méditerranéens, Quelles recherches pour y répondre, Proceedings of the plenary sessions of the Elche International Workshop on Date Cultivation in Oasis Agriculture of Mediterranean Countries.

57. RDO (2010) Resilient Drylands and Oases Committed Territories, Resilient drylands and oases, committed territories Cancunmesse 
Citation: Karmaoui A, Ifaadassan I, Messouli M, Khebiza MY (2015) Sustainability of the Moroccan Oasean System (Case study: Middle Draa Valley). Global J Technol Optim 6: 170. doi:10.4172/2229-8711.1000170

Page 9 of 9

Mexico, Drylands Development Center (UNDP) and the Government of Finland.
58. Schulz O, Judex M (2008) Impetus Atlas Morocco: Research results 2000-2007, University of Bonn, Bonn, Germany 79. 